\title{
DNA Sequence Alteration Process
}

National Cancer Institute

\section{Source}

National Cancer Institute. DNA Sequence Alteration Process. NCI Thesaurus. Code C21068.

Any subcellular process affecting molecular sequence that results in a specific and defined change in the primary sequence of a double-stranded DNA. 